\title{
Comparative radiotracer study of cadmium uptake, storage, detoxification and depuration in the oyster Crassostrea gigas: potential adaptive mechanisms
}

\author{
F. Boisson ${ }^{1, *}$, F. Goudard ${ }^{2}$, J. P. Durand ${ }^{2}$, C. Barbot ${ }^{2}$, J. Pieri², J. C. Amiard ${ }^{3}$, \\ S. W. Fowler ${ }^{1}$ \\ ${ }^{1}$ International Atomic Energy Agency, Marine Environment Laboratory, 4 Quai Antoine Ier, BP 800, 98012 Monaco Cedex, \\ Principality of Monaco \\ ${ }^{2}$ Faculté des Sciences et des Techniques, GERMETRAD, Laboratoire de Biochimie et Radiobiochimie, and \\ ${ }^{3}$ Service d'Ecotoxicologie, CNRS GDR 1117, Université de Nantes, ISOMer, SMAB, 2 rue de la Houssinière, BP 92208, \\ 44322 Nantes Cedex 3, France
}

\begin{abstract}
The bioaccumulation of cadmium in the oyster Crassostrea gigas originating from a clean (Bourgneuf Bay) and a chronically Cd-contaminated area (Gironde estuary) experimentally exposed to ${ }^{109} \mathrm{Cd}$-labeled bulk seawater (dissolved and particulate pathways combined) was examined over $21 \mathrm{~d}$. A single-component first-order kinetic model describing the behavior of the bioaccumulation factor (BAF) throughout the experiment showed that the estimated Cd BAF at $21 \mathrm{~d}$ was $47 \%$ higher for oysters originating from the contaminated estuary than for oysters from the clean area, suggesting an influence of the previous chronic exposure to Cd contamination in the estuarine environment. From the experimental results, the potential adaptive mechanism suggested cannot be attributed to a reduction in Cd permeability but rather to a higher Cd turnover due to the synergy between lysosomes and metallothioneins which, through chelation, are responsible for the reduction in bioavailability and toxicity of cd in oysters. The lower BAF observed for soft parts of oysters previously exposed to chronic $\mathrm{Cd}$ contamination corresponded to a faster response to the experimental $\mathrm{Cd}$ contamination due to the presence of pre-existing metallothioneins induced by the $\mathrm{Cd}$ present in the estuarine environment. Furthermore, based on a 2-component exponential loss kinetic model, Cd complexation to metallothioneins and lysosomes was probably responsible for the slow turnover in the long-term compartment of loss (biological half-life, $T_{b 1 / 2}=495$ and $198 \mathrm{~d}$ for the Bourgneuf and the Gironde oysters, respectively). Of the total $\mathrm{Cd}$ accumulated, 40 to $60 \%$ was in the soluble form and 30 to $40 \%$ of this fraction had been detoxified by the Gironde oysters through chelation to metallothioneins or to lysosomes, which means that approximately 12 to $24 \%$ of the total Cd accumulated was potentially bioavailable to humans through oyster consumption. However, through depuration, it was also more efficiently eliminated from oyster soft parts (the edible portion) previously exposed to $\mathrm{Cd}$ than from control oysters. Therefore, in the light of these results, it is suggested that the way in which regulatory thresholds of $\mathrm{Cd}$ in oysters are presently calculated should be reconsidered and should take into account the level of $\mathrm{Cd}$ already detoxified by the oysters through complexation processes.
\end{abstract}

KEY WORDS: Cadmium - Radiotracer · Oysters · Uptake $\cdot$ Depuration · Subcellular fractionation · Adaptive mechanisms

\section{INTRODUCTION}

In the marine environment, estuarine zones are subjected to periodic anthropogenic contamination by trace metals. In areas where oyster culture is devel- oped, this situation has a potential socio-economic impact, since oysters are known for their ability to concentrate metals from their environment, in particular the highly toxic contaminant cadmium (Amiard 2002). The Gironde estuary (France) has been devoted to 
oyster culture; however, it is also chronically enriched with Cd (Latouche 1988, 1992). Latouche (1992) demonstrated that the $\mathrm{Cd}$ pollution mainly originates from the wastes of a $\mathrm{Cd}$ plant in an industrial zone located in a principal drainage basin. Particulate $\mathrm{Cd}$ transported by the rivers changes in the Gironde estuary is solubilized as a consequence of the increase in salinity. It is accumulated not only by the oysters on the inner shelf and at the estuary mouth, but also by the sediment, which serves as pollutant reservoir. Geffard et al. (2002) demonstrated that the Cd concentration in oysters from the metal-rich Gironde estuary can be as much as 15 times higher than that in oysters from an area (Bay of Bourgneuf, France) considered to be relatively free of pollution (Amiard-Triquet 1987a).

A key aspect of this study was to define potential adaptive mechanisms developed by oysters subjected to chronic $\mathrm{Cd}$ contamination in the environment. A novel experimental approach was used to determine whether the behavior and fate of $\mathrm{Cd}$ in the oyster Crassostrea gigas are different in organisms originating from a Cd-contaminated area (Gironde estuary) than in those from a relatively clean site (Bay of Bourgneuf) when both are experimentally exposed to an elevated stable Cd level. The bioaccumulation potential of this benthic bivalve was evaluated prior to subcellular analyses. A non-destructive method which allows determination of individual uptake kinetics was used to measure the bioaccumulation potential. In this approach, the radioactive isotope ${ }^{109} \mathrm{Cd}$ was used together with the stable metal to evaluate the bioaccumulation potential of the 2 populations of oysters experimentally stressed by the stable metal. This method is used to identify the relative distribution of the radiotracers at the organism, cellular and subcellular level in order to highlight potential adaptive mechanisms to Cd contamination which could be of ecotoxicological significance. In fact, Cd toxicity (nephrotoxicity, osteotoxicity) has been observed in man in France (itaï itaï disease, in Boisset 1996a), and has led to legal restrictions on oyster production and marketing in regions where Cd concentrations in soft tissues exceed $2 \mathrm{mg} \mathrm{kg}^{-1}$ wet wt (Boisset 1996b). As a consequence, oyster farms have been closed in the Gironde estuary. Recently, a European regulation (CE N466/2001: Communautés Européennes 2001) lowered this threshold to $1 \mathrm{mg} \mathrm{kg}^{-1}$. The results of the present study indicate the need for reconsidering the way in which the regulatory thresholds of Cd in oysters are calculated.

\section{MATERIALS AND METHODS}

Uptake of cadmium from food and seawater. Oysters Crassostrea gigas of similar size (5 to $6 \mathrm{~cm}$ ) were harvested in early March at 2 sites along the Atlantic coast of France, the Gironde estuary (GE) near the most highly Cd-contaminated area of the French coast (RNO 1995) and the Bay of Bourgneuf (BB), which is considered to be an uncontaminated area (AmiardTriquet 1987b). Oysters were transported refrigerated to the laboratory, where they were thoroughly washed to remove encrusting organisms, and then acclimated to laboratory conditions (Mediterranean seawater, $17 \pm$ $1^{\circ} \mathrm{C}, 37 \%$ psu and $12: 12 \mathrm{~h}$ light:dark regime) for $2 \mathrm{wk}$ prior to the start of the experiment.

An aquarium filled with 501 of Mediterranean seawater was spiked with microliter quantities of the radiotracer ${ }^{109} \mathrm{Cd}$ in acidic solution (carrier-free, obtained from AEA Technology, $t_{1 / 2}=462.3 \mathrm{~d}$ ) to obtain an activity of $2 \mathrm{kBq} \mathrm{l}^{-1}$ in the experimental medium. No change in $\mathrm{pH}$ was observed after this addition. The medium, which naturally contained approximately 72.3 pM of stable Cd (Fisher et al. 2000), was also enriched with stable $\mathrm{Cd}$ at a concentration of $500 \mathrm{ng} \mathrm{Cd} \mathrm{^{-1 }}$ (4.45 nM 1 $\left.{ }^{-1}\right)$ to correspond to the environmental level of $\mathrm{Cd}$ in the Gironde estuary reported by Latouche (1988). Following radioactive and stable $\mathrm{Cd}$ addition, the experimental medium was allowed to equilibrate for $2 \mathrm{~h}$. The initial ${ }^{109} \mathrm{Cd}$ activity in the seawater was checked, and then 60 individuals from each sampling site were placed in the aquarium. The shell of each individual was previously tagged to allow identification. Oysters were fed the prymnesiophyceaen Isochrysis galbana at an initial algal cell density of $10^{4} \mathrm{ml}^{-1}$ in the experimental medium. This food concentration was chosen to prevent as much as possible the production of fecal pellets (Luoma et al. 1992, Wang et al. 1996) and to avoid recycling of ${ }^{109} \mathrm{Cd}$. The experimental medium was changed every $2 \mathrm{~d}$ to maintain ${ }^{109} \mathrm{Cd}$ activity at a relatively constant level. On each sampling occasion, 10 oysters each from the contaminated and the control site were removed, briefly rinsed in fresh seawater, blotted dry on absorbent paper to eliminate any adhering radioactive medium, and weighed before being gamma-counted. The individual uptake kinetics of ${ }^{109} \mathrm{Cd}$ in each individual oyster were followed over $2 \mathrm{wk}$.

Cadmium depuration. At the end of the uptake period, the radioactivity of 53 oysters from each group (i.e. sampling cite) was determined; of these 53 individuals, 3 were dissected to evaluate the $\mathrm{Cd}$ distribution in their tissues, i.e. shell, remaining soft parts, gills, pallial fluid and the remainder adhering to the dissection tools. Cd distribution was also examined at the subcellular level in 20 individuals. The remaining 30 individuals were placed in fresh flowing seawater and allowed to eliminate the radioisotope. During the depuration phase, the oysters were continuously fed, 
and 10 oysters (always the same individuals) from the Gironde estuary and the Bay of Bourgneuf were periodically removed and counted; at each sampling, 3 oysters from those remaining were dissected to determine the tissue distribution of ${ }^{109} \mathrm{Cd}$.

Subcellular analysis. At the end of the ${ }^{109} \mathrm{Cd}$ exposure period, 20 oysters from both the Gironde estuary and Bourgneuf Bay were dissected and their visceral masses removed for subcellular analysis. Visceral tissues were pooled and homogenized in $0.25 \mathrm{M}$ sucrose, $5 \mathrm{mM}$ 2-mercaptoethanol, $0.1 \mathrm{mM}$ phenylmethyl sulfoxyl fluoride, and $20 \mathrm{mM}$ Tris- $\mathrm{HCl}$ at $\mathrm{pH}$ 8. Cell fractionation procedures were carried out at $4^{\circ} \mathrm{C}$. Subcellular fractions were obtained by differential centrifugation according to the procedure described by Galey et al. (1986). The homogenate was centrifuged successively at $900 \times g$ for $10 \mathrm{~min}$ to sediment nuclei, cell debris and heavy lysosomes, at $12000 \times g$ for 15 min to sediment lysosomes and the mitochondrial fraction, at $45000 \times g$ for $30 \mathrm{~min}$ to sediment the light mitochondrial fraction and cellular membranes, and at $115000 \times g$ for 70 min to obtain the microsomal fraction in the pellet and the cytosolic fraction in the supernatant. Aliquots were taken from each fraction for determination of ${ }^{109} \mathrm{Cd}$ activity and enzymatic activities of a marker for lysosomes (acid phosphatase assay as described by Galey et al. 1986).

The cytosolic fraction obtained in the final centrifugation was fractionated according to the molecular size by gel permeation chromatography on a column of Sephacryl S300 $(2.6 \times 95 \mathrm{~cm})$ previously equilibrated with $100 \mathrm{mM} \mathrm{NaCl}, 5 \mathrm{mM}$ 2-mercaptoethanol and $20 \mathrm{mM}$ Tris- $\mathrm{HCl}$ at $\mathrm{pH} 8$. The column was eluted at a flow rate of $33 \mathrm{ml} \mathrm{h}^{-1}$. Fractions of $4 \mathrm{ml}$ were collected and analyzed for ${ }^{109} \mathrm{Cd}$ radioactivity and for absorbance at $280 \mathrm{~nm}$ (Varian Cary 50 spectrophotometer). Calibration of the column was performed with different molecular weight markers: thyroglobulin $669 \mathrm{kDa}$, ferritin $440 \mathrm{kDa}$, catalase $232 \mathrm{kDa}$, aldolase $158 \mathrm{kDa}$, bovine serum albumin $67 \mathrm{kDa}$, chymotrypsinogen A $25 \mathrm{kDa}_{\text {, }}$ and ribonuclease $13.7 \mathrm{kDa}$.

Nuclear detection. The $\gamma$ emission of ${ }^{109} \mathrm{Cd}(88.0 \mathrm{keV})$ in oysters, seawater and dissected tissues was determined using a well-type NaI detector connected to a multichannel analyzer and a personal computer using Interwinner ${ }^{\mathrm{TM}}$ software for spectral analysis. The activity in the tissue fractions was analyzed with an automatic well-type NaI Packard Cobra II counter. The ${ }^{109} \mathrm{Cd}$ radioactivity in samples was determined by comparison with standards of appropriate geometry and was corrected for background, counting efficiency and radioactive decay. Counting times were adjusted to give relative propagated errors $<5 \%$ at $1 \mathrm{SD}$ level, i.e.
$3 \mathrm{~min}$ for oysters and seawater, and from $20 \mathrm{~min}$ to $1 \mathrm{~h}$ for dissected body tissues.

Data analysis. Uptake from water and diet is usually reported as bioaccumulation factors (BAF) which are calculated at each sampling time as: activity in oyster (Bq g ${ }^{-1}$ wet wt)/total ambient activity $\left(\mathrm{Bq} \mathrm{m}{ }^{-1}\right)$, where total ambient activity corresponds to the bulk seawater representing dissolved and dietary cadmium sources. To reduce the influence of temporal fluctuations of the activity level in the labeled seawater, the radioactivity of the seawater used for each calculation was obtained by computing a running mean of the ${ }^{109} \mathrm{Cd}$ activities in seawater measured on each sampling day and after each new spike.

Cd uptake kinetics were fitted by a simple linear regression model $\mathrm{BAF}=k t$, where $k$ is the regression slope corresponding to the rate of increase in BAF $\left(\mathrm{d}^{-1}\right.$ and $t$ is time in days). Linearity of the uptake kinetics was tested by 1-way ANOVA for regression with replication.

Cadmium loss was determined by dividing the radioactivity in the whole body during the depuration phase (normalized to the wet weight of the organism) by the radioactivity measured at the end of the exposure period (Bq g ${ }^{-1}$ wet $\mathrm{wt}_{\text {; }}$ time, $t=15 \mathrm{~d}$ ) to give the percentage of cadmium remaining in the organism at a given time. The $\%{ }^{109} \mathrm{Cd}$ retained in the whole body was plotted against time for each individual from each group of oysters. The mean loss kinetics obtained were described by a 2-component exponential model including a shortlived $(s)$ and a long-lived (l) component (Whicker \& Schultz 1982):

$$
A_{t}=A_{0 s} \mathrm{e}^{-\lambda s t}+A_{0 l} \mathrm{e}^{-\lambda l t}
$$

where $A_{t}$ and $A_{0}$ are the remaining activities (\%) in oysters at time $t(\mathrm{~d})$ and zero, respectively, and $\lambda$ is the biological depuration rate constant $\left(\% \mathrm{~d}^{-1}\right)$ corresponding to the regression slope. Adjustment of the data distribution to the model was tested by a 1-way ANOVA.

Biological half-lives of $\mathrm{Cd}$ were computed for the short-term $\left(T_{b 1 / 2 s}\right)$ and the long-term $\left(T_{b 1 / 21}\right)$ components using the corresponding depuration rate constants in the following equation (Whicker \& Schultz 1982):

$$
T_{b 1 / 2}=\ln 2 / \lambda
$$

The same procedure was applied for the assessment of $\mathrm{Cd}$ retention by the body compartments during the loss period. Difference between the slopes of the regression equations obtained for loss in oysters from the contaminated and from the control area was tested by Student's $t$-test. The level of significance for statistical analyses was set at $\alpha=0.05$. 


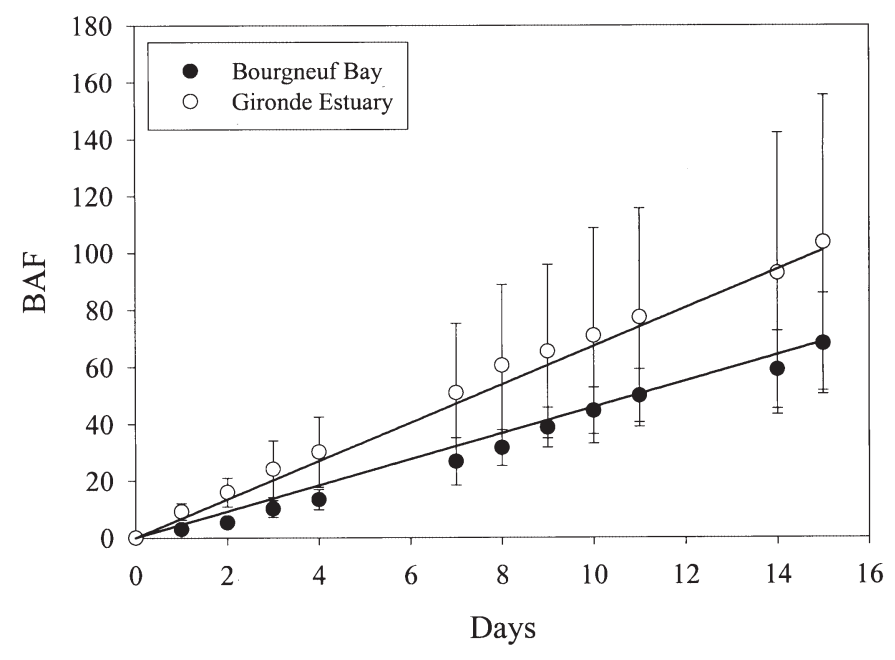

Fig. 1. Crassostrea gigas. Uptake of ${ }^{109} \mathrm{Cd}$ in whole oysters originating from a contaminated area (Gironde Estuary) and from clean area (Bourgneuf Bay) following exposure to labeled food and seawater in the presence of $500 \mathrm{ng} \mathrm{l}^{-1}$ stable $\mathrm{Cd}$ (mean $\pm 1 \mathrm{SD}, \mathrm{n}=10$ individuals). BAF: bioaccumulation factor

\section{RESULTS}

\section{Cadmium uptake}

Stable Cd was added to the experimental medium together with the radiotracer corresponding to dissolved Cd concentrations in the most polluted estuaries, to deliberately stress the organisms in order to demonstrate the presence of any adaptive response in oysters previously subjected to chronic Cd contamination in their natural environment.

The whole-body uptake of radioactive $\mathrm{Cd}$ from bulk seawater by both groups of oysters displayed linear kinetics over the $15 \mathrm{~d}$ exposure period (Fig. 1). From the fitting of the data, using a linear uptake model $\left(\mathrm{R}^{2}=0.988\right.$ and 0.975 for the Gironde and the Bourgneuf areas, respectively; $\mathrm{p}<0.0001$ ), it is estimated that the rate of increase of the bioaccumulation factors in the oysters was $k=6.73 \pm 0.23$ and $k=4.58 \pm 0.23(\mathrm{p}<0.0001)$ for the contaminated and for the control sites, respectively. The regression slopes were significantly different at the 0.05 level. The ${ }^{109} \mathrm{Cd}$ BAFs obtained at the end of the 2-wk exposure period were $104 \pm 52$ for the oysters taken from the contaminated zone (Gironde Estuary, GE) and $68 \pm 18$ for the oysters originating from the clean area (Bourgneuf Bay, BB).

At the end of the exposure period, 3 individuals from each group of oysters were whole-body counted and dissected into shell, soft parts, gills, pallial fluid and remainder. Cd BAFs were then computed for each compartment (Table 1). There was no significant dif-
Table 1. Crassostrea gigas. Cd bioaccumulation factors, BAF (mean $\pm 1 \mathrm{SD} ; \mathrm{n}=3$ ind.) in body compartments of oysters from contaminated Gironde Estuary and from 'clean' Bourgneuf Bay, following $15 \mathrm{~d}$ experimental exposure to Cd contamination from both food and dissolved sources

\begin{tabular}{|lcc|}
\hline Compartments & Gironde Estuary & Bourgneuf Bay \\
\hline Shell & $29.6 \pm 19.2$ & $21.6 \pm 3.3$ \\
Soft Parts & $894.8 \pm 131.8$ & $1474.5 \pm 404.6$ \\
Gills & $2771.9 \pm 1515.7$ & $1916.5 \pm 642.5$ \\
Pallial Fluid & $7.2 \pm 1.9$ & $5.7 \pm 0.2$ \\
\hline
\end{tabular}

ference between the 2 groups of oysters for the BAFs of shell, gills and pallial fluid, but the soft parts of BB oysters concentrated significantly more Cd (40\%) than the soft parts of the GE oysters ( $t$-test, $\mathrm{p}<0.05)$.

With respect to the distribution of ${ }^{109} \mathrm{Cd}(\mathrm{Bq})$ among body compartments, it appears that the major fraction of radiocadmium is located in the soft parts, followed by gills, shell and pallial fluid, with the remainder containing only a few percent (Fig. 2). The fraction of total $\mathrm{Cd}$ in the shell was significantly higher in the GE oysters than in the BB group, whereas ${ }^{109} \mathrm{Cd}$ concentration in the soft parts of BB oysters was higher than that in the from the GE. There were no observed difference for the other compartments in these 2 groups of oysters ( $t$-test, $\mathrm{p}<0.05)$.

The subcellular distribution of ${ }^{109} \mathrm{Cd}$ in the digestive gland of oysters at the end of the exposure period was determined by homogenization of the digestive gland, and separation of cellular organelles and membrane fragments from the soluble cytosolic components by differential centrifugation on the basis of their various densities (Table 2). The ${ }^{109} \mathrm{Cd}$ activity was distributed

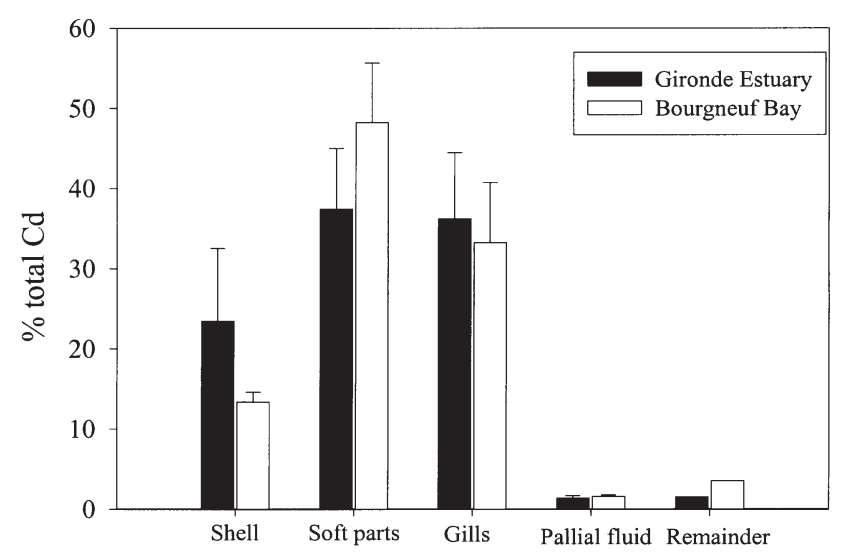

Fig. 2. Crassostrea gigas. ${ }^{109} \mathrm{Cd}$ distribution in body compartments of oysters from the contaminated (Gironde) and control (Bourgneuf) areas at end of exposure period. Data are mean $+1 \mathrm{SD}$ ( $\mathrm{n}=3$ ind.) 
in the various subcellular compartments with a predominance in the soluble fraction (59.8 and $41.2 \%$ of ${ }^{109} \mathrm{Cd}$ for $\mathrm{GE}$ and $\mathrm{BB}$ oysters, respectively). The remaining ${ }^{109} \mathrm{Cd}$ activity was distributed among the other compartments, principally in the heavy fraction: first pellet (nuclei, heavy lysosomes, cellular debris) $=15.5 \%$ GE, 30.2\% BB; second pellet (lysosomes, mitochondria) $=15.7 \%$ GE, $16.8 \%$ BB. The ${ }^{109} \mathrm{Cd}$ activity was approximately $30 \%$ higher in the cytosol of GE oysters than in that of BB individuals, with the heavy fraction in $\mathrm{BB}$ oysters being more contaminated than in the same fraction of the GE oysters.

The distribution analysis of the enzymatic marker (acid phosphatase) showed that most of the activity was in the first 3 centrifuged pellets, with a maximum in the second pellet for both groups of oysters, indicating the presence of most of the lysosomes in this pellet.

The cytosolic fractions of the digestive gland of oysters which contained 59.8 and $41.2 \%$ of ${ }^{109} \mathrm{Cd}$ were fractionated by size-exclusion chromatography on a Sephacryl S300 column to identify the different molec-
Table 2. Crassostrea gigas. Distribution of ${ }^{109} \mathrm{Cd}$ in subcellular fractions of visceral mass as percentage recovered ${ }^{109} \mathrm{Cd}$ radioactivity (\% Bq) and enzymatic activities of lysosome markers (acid phosphatase, \% AP)

\begin{tabular}{|c|c|c|c|c|}
\hline \multirow[t]{2}{*}{ Cell fraction } & \multicolumn{2}{|c|}{ Gironde Estuary } & \multicolumn{2}{|c|}{ Bourgneuf Bay } \\
\hline & $\% \mathrm{~Bq}$ & $\% \mathrm{AP}$ & $\% \mathrm{~Bq}$ & $\% \mathrm{AP}$ \\
\hline $\begin{array}{l}\text { Nuclei, cell debris, } \\
\text { heavy lysosomes }\end{array}$ & 15.5 & 16.5 & 30.2 & 15.7 \\
\hline $\begin{array}{l}\text { Lysosomes, } \\
\text { mitochondria }\end{array}$ & 15.7 & 25.1 & 16.8 & 17.5 \\
\hline $\begin{array}{l}\text { Light lysosomes, } \\
\text { membranes }\end{array}$ & 4.4 & 14.3 & 6.4 & 15.1 \\
\hline Microsomes & 4.6 & 7.7 & 5.4 & 9.0 \\
\hline Cytosol & 59.8 & 36.4 & 41.2 & 42.7 \\
\hline
\end{tabular}

ular components responsible for Cd fixation (Fig. 3): 30 to $40 \%$ of the cytosolic cadmium was located on a peak with a $K_{\mathrm{av}}$ (distribution coefficient) between 0.6 and 0.7 and an apparent molecular weight of $9 \mathrm{kDa}$, regardless of the origin of the oysters. This fraction cor-
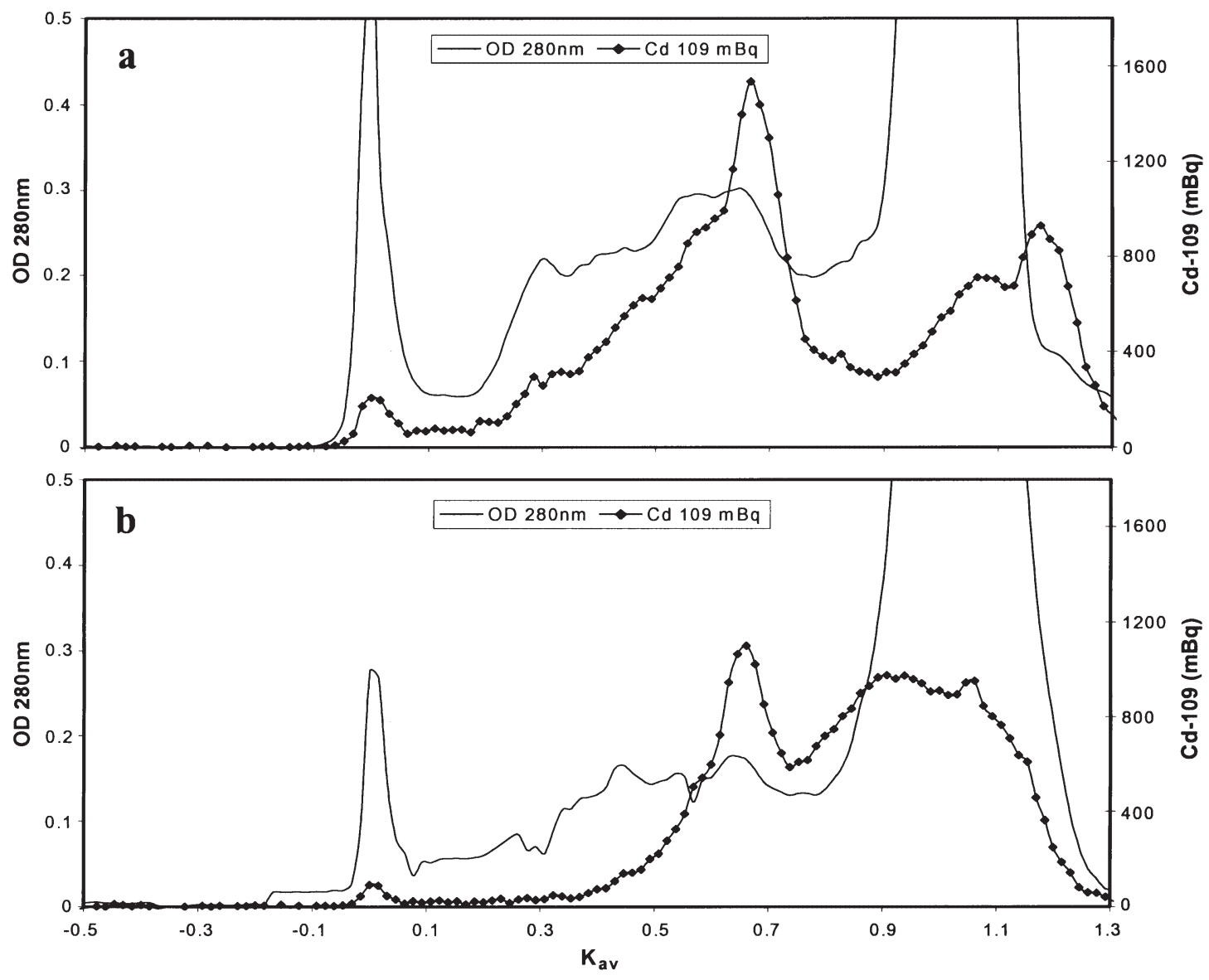

Fig. 3. Crassostrea gigas. Fractionation of cytosol from visceral mass of Gironde Estuary (a) and Bourgneuf Bay (b) oysters on a Sephacryl S300 column. Distributions of ${ }^{109} \mathrm{Cd}$ activity $(\mathrm{mBq})$ and protein content measured by absorbance at $280 \mathrm{~nm}(\mathrm{OD}=\mathrm{optical}$ density) are shown; distribution coefficient of the protein is defined by $K_{a v}=\left(V_{e}-V_{o}\right) /\left(V_{t}-V_{o}\right)$, with $V_{e}=$ elution volume of the protein, $\mathrm{V}_{\mathrm{o}}=$ void volume, $\mathrm{V}_{\mathrm{c}}=$ total volume of the column 
responds to the elution volume of metallothioneins which play an important role in the metal detoxification process in bivalves and other species.

In the cytosolic fraction of the GE oysters, some proteins of higher molecular weight were associated with the ${ }^{109} \mathrm{Cd}$ activity; whereas in the BB oysters, proteins with molecular weight higher than $9 \mathrm{kDa}$ contained a very low level of ${ }^{109} \mathrm{Cd}$, which was mainly associated with low molecular weight components.

\section{Cadmium elimination}

At the end of the exposure period, the oysters from both groups were transferred to uncontaminated seawater and were maintained for $41 \mathrm{~d}$ to follow $\mathrm{Cd}$ depuration from each individual oyster. The mean loss kinetics obtained for each group of oysters were best described by a 2-component exponential model (Fig. 4, Table 3).

Depuration of ${ }^{109} \mathrm{Cd}$ appears to be a slow process; the short-lived loss components were characterized by a short biological half-life of 2 and $10 \mathrm{~d}$ for oysters from

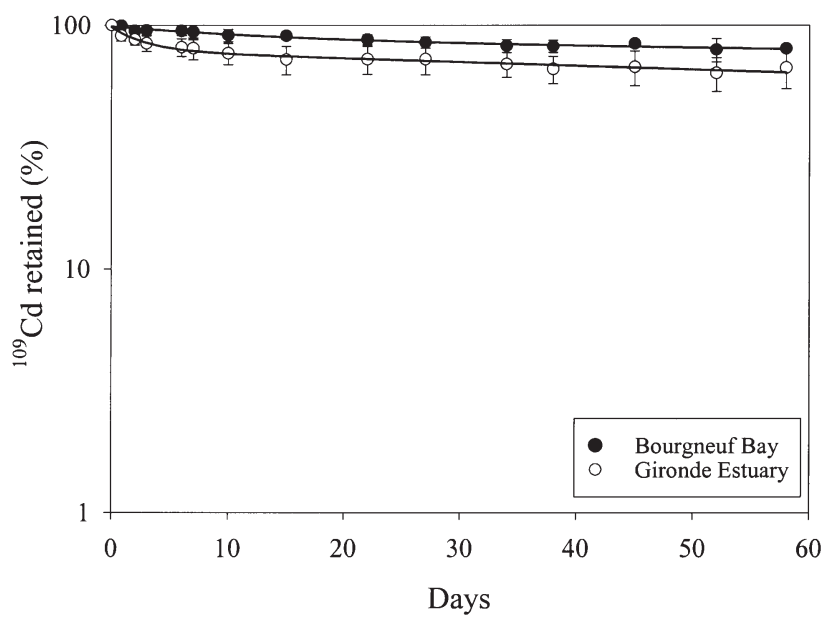

Fig. 4. Crassostrea gigas. Loss of ${ }^{109} \mathrm{Cd}$ in whole oysters from contaminated (Gironde Estuary) and clean (Bourgneuf Bay) areas following $15 \mathrm{~d}$ exposure to labeled food and seawater (average $\pm 1 \mathrm{SD}$ individual loss kinetics, $\mathrm{n}=10$ individuals). Parameters for equation fitting the data are given in Table 3 the contaminated and the control areas, respectively. It is estimated that the short-lived loss components $\left(A_{0 s}\right)$ represent $19.8 \pm 2.3 \%(\mathrm{p}<0.0001)$ of the total Cd activity of the oysters from the contaminated area and $12.7 \pm$ $9.7 \%(\mathrm{p}<0.0001)$ for those from the control estuary. The long-lived loss component was associated with the majority of the Cd accumulated at the end of the exposure period, i.e. $78.3 \pm 1.8 \%(p<0.0001)$ and $86.1 \pm$ $10.1 \%(p<0.0001)$ in the GE and the BB oysters, respectively. Depuration from this long-lived loss component, representing the firmly bound $\mathrm{Cd}$, was very slow, resulting in a biological half-life of 198 and $495 \mathrm{~d}$ for the contaminated and control groups, respectively.

Comparison of the regression slopes obtained for the short-lived component indicated that the Cd elimination rate was significantly higher for the oysters living in the GE whereas no significant difference between the 2 groups of oysters was noted for the long-lived ${ }^{109} \mathrm{Cd}$ loss components.

\section{Cadmium distribution among body compartments during depuration}

Comparison of the relative radiotracer content (\% Bq) in body tissues of Crassostrea gigas over the depuration period (Fig. 5) indicated that the $\mathrm{Cd}$ associated with shell, gills and pallial fluid represented a higher fraction of the total $\mathrm{Cd}$ accumulated in the GE oysters than in the $\mathrm{BB}$ oysters, with the latter containing a higher fraction of $\mathrm{Cd}$ in the soft parts. Moreover, the $\mathrm{Cd}$ distribution among body compartments did not remain constant throughout the loss experiment. The relative $\mathrm{Cd}$ content of the shell and the gills decreased with increasing depuration time, while the relative Cd content of the soft parts increased and that for the pallial fluid remained approximately constant.

\section{DISCUSSION}

Analysis of the biokinetics of heavy metals such as $\mathrm{Cd}$ using conventional methods in experiments is difficult to undertake at environmental levels of contami-

Table 3. Crassostrea gigas. Parameters and statistics of equations describing Cd loss kinetics for oysters originating from Gironde and Bourgneuf Bay areas: 2-component exponential model $A_{t}=A_{0 s} \mathrm{e}^{-\lambda s t}+A_{0 l} \mathrm{e}^{-\lambda l t}$, where $A_{t}=$ remaining activity (\%) in oysters at time $t(\mathrm{~d}), A_{0 s}$ and $A_{0 l}=$ remaining activity (\%) in oysters at time zero for short-term $(s)$ and the long-term $(l)$ components, $\mathrm{R}^{2}=$ determination coefficient, $k=$ rate constant $\left(\mathrm{d}^{-1}\right), T_{b 1 / 2 s}$ and $T_{b 1 / 2 l}=$ biological half-life in days, and ASE = asymptotic standard error

\begin{tabular}{|c|c|c|c|c|c|c|c|c|}
\hline Site & $\begin{array}{c}A_{0 s} \\
\text { (ASE) }\end{array}$ & $\begin{array}{c}k_{\mathrm{s}} \\
\text { (ASE) }\end{array}$ & $\begin{array}{c}T_{b 1 / 2 s} \\
\text { (ASE) }\end{array}$ & $\begin{array}{c}A_{01} \\
\text { (ASE) }\end{array}$ & $k_{l}$ & $T_{b 1 / 21}$ & $\mathrm{R}^{2}$ & $\mathrm{p}$ \\
\hline Bourgneuf Bay & $12.72(9.69)$ & $0.0647(0.0557)$ & 10.7 & $86.14(10.06)$ & $0.0014(0.0019)$ & 495 & 0.96 & $<0.001$ \\
\hline Gironde Estuary & $19.79(2.28)$ & $0.3410(0.0941)$ & 2.03 & $78.26(1.84)$ & $0.0035(0.0007)$ & 198 & 0.97 & $<0.001$ \\
\hline
\end{tabular}



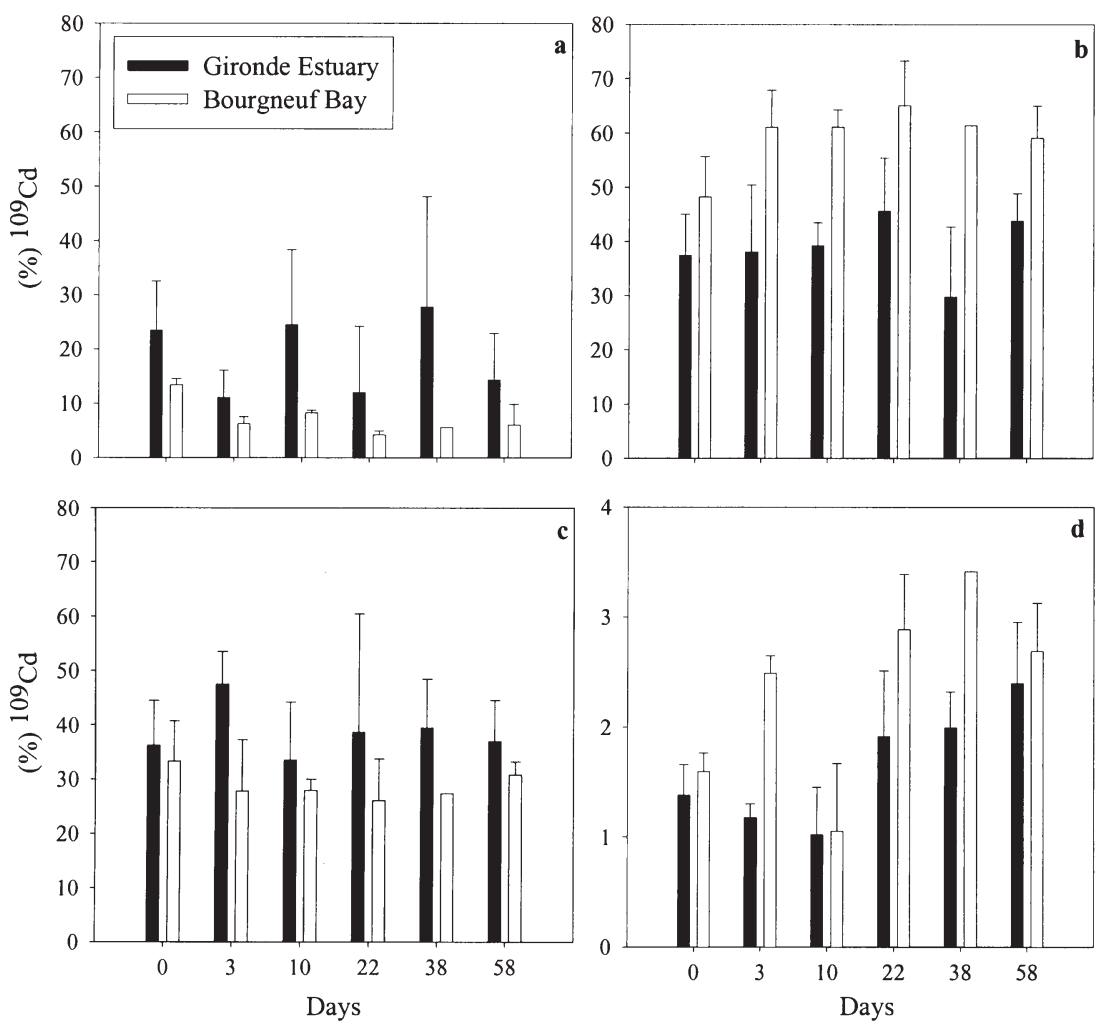

Fig. 5. Crassostrea gigas. Percentage of whole-body ${ }^{109} \mathrm{Cd}(\mathrm{Bq})$ retained in shell (a), soft parts (b), gills (c) and pallial fluid (d) over depuration period (mean \% activity $+1 \mathrm{SD} ; \mathrm{n}=3$ individuals)

nation because of the relatively low amounts of trace metals present. Moreover, organisms must be sacrificed to determine their $\mathrm{Cd}$ content and their $\mathrm{Cd}$ uptake kinetics. In contrast, the use of carrier-free radiotracer ${ }^{109} \mathrm{Cd}$ as a non-destructive method allows the uptake and depuration kinetics of a single individual to be followed over time at natural Cd levels, and also a more adequate assessment of the behavior of the $\mathrm{Cd}$ in oysters, by reducing the influence of inherent natural variability between different organisms (with dissections being performed as a complementary method for specifically determining intracellular $\mathrm{Cd}$ ).

The fact that Cd was distributed in both the gills and soft parts indicates that both the dissolved and the food pathways contributed to the transfer of $\mathrm{Cd}$ to the oysters. The BAF had not approached a steady state by the end of the $15 \mathrm{~d}$ exposure period. The singlecomponent first-order kinetic model describing the behavior of the BAF throughout the experiment showed that the estimated Cd BAF after $15 \mathrm{~d}$ exposure was $47 \%$ higher for oysters previously exposed to elevated levels of $\mathrm{Cd}$ in their natural environment than for oysters originating from an uncontaminated area. This suggests that the former had not developed a resistance to $\mathrm{Cd}$ contamination through a reduction in $\mathrm{Cd}$ permeability. Part of this additional $\mathrm{Cd}$ was associated with the shell which represented a significantly higher percentage of the total body burden than was the case for oysters from the control area. This was probably connected with the rough shell surface of the Gironde oysters, which offered a greater surface area for adsorption than the relatively smooth shell of oysters from the Bay of Bourgneuf. The other fraction of additional $\mathrm{Cd}$ was located in the gills: the previously contaminated oysters bio-concentrated $30 \%$ more $\mathrm{Cd}$ than the gills of oysters from the control area (although this difference was not significant due to a high SD). A similar linear Cd uptake pattern was reported by $\mathrm{Lu}$ et al. (1998) for the oyster Crassostrea rivularis experimentally contaminated by dissolved $\mathrm{Cd}$. Furthermore, it has been demonstrated in some molluscs that $\mathrm{Cd}$ accumulation rates and body burdens are greater in organisms that produce metallothioneins than in those in which induction is weak (Langston \& Spence 1995). Thus, our results in general suggest that oysters chronically exposed to environmental Cd contamination develope an adaptive mechanism through an enhanced ability to detoxify the metal internally.

In order to test this hypothesis of adaptive response, we chose the visceral masses of the oysters to examine the subcellular fractionation, since a predominant proportion of Cd was present in their soft parts. The highest percentage of $\mathrm{Cd}$ was found in the cytosolic fraction of oysters from both sites. The other fraction with a notable amount of $\mathrm{Cd}$ was the 'heavy' fraction, which contained the nuclei, heavy lysosomes and cellular debris. This latter fraction is comparable to the 'insoluble' fraction obtained by other authors using different methods (Mouneyrac et al. 1998, Geffard et al. 2001). In the BB oysters, the heaviest fractions-nuclei, heavy lysosomes and cellular debris or lysosomes and mitochondria-contained up to $47 \%$ of the total $\mathrm{Cd}$.

In the cytosol of oysters from both areas, chromatographic analysis revealed an elevated fraction of $\mathrm{Cd}$ in the elution range of metallothioneins. Metalloprotein, ubiquitous in various organisms, is a cystein-rich protein which plays an important role in metal detoxification (Kägi \& Vallee 1960, Binz \& Kägi 1999), and has been well documented in oysters (Butler \& Roesijadi 2001, Tanguy et al. 2001). The distribution of Cd between the metallothioneins and the lysosomal vacuolar 
system has been described by other authors (George 1990, Viarengo \& Nott 1993).

Chromatography of the cytosol of GE oysters indicated a low amount of $\mathrm{Cd}$ associated with the high molecular weight proteins. The presence of high molecular weight Cd-binding proteins in cytosols of contaminated marine animals was discussed by George (1982), who suggested that 'spill over' of Cd occurred when the binding capacity of metallothioneins was exceeded. Nevertheless, there is still some doubt about the origin of these high molecular weight proteins, because some may comprise an aggregation of metal-binding proteins or metallothionein dimers (Engel 1999).

Some Cd appeared to be associated with low molecular weight molecules in the cytosolic fraction of the BB oysters. This observation has been reported frequently for oysters (Coombs 1974, Frazier \& George 1983, Fayi \& George 1985, Isani et al. 2000). Fayi \& George (1985) showed that these metal-binding components, with molecular weights lower than $<2 \mathrm{kDa}$ may be peptides such as Gly-Gly and Cys-Gly and some complexes of glutathion (GSH: rglutamylcysteinyl-glycine). According to Mason \& Jenkins (1995), this component may be important during the first phase of contamination when the concentration of induced metallothioneins is still too low to have a protective effect.

In our study, we observed different proportions of $\mathrm{Cd}$ radiotracer between the 2 compartments (i.e. lysosomes and cytosolic metallothioneins) involved in $\mathrm{Cd}$ accumulation, depending on the origin of the oysters (contaminated or clean site). The abundance of this metal in the cytosol of GE oysters at the end of the exposure period could be attributable to the presence of pre-existing metallothioneins induced by chronic $\mathrm{Cd}$ contamination of the estuarine environment. For the $\mathrm{BB}$ oysters, constitutive forms of $\mathrm{Zn}$ metallothioneins (Engel 1999) could be present. These metallothioneins are necessary for the regulation of the high levels of Zn naturally present in feral oysters (Roesijadi 1996). Since Cd shows a greater affinity for metallothionein SH-groups than zinc (Geret \& Cosson 2000), it is possible that $\mathrm{Cd}$ replaces $\mathrm{Zn}$ in the metallothioneins during contamination (Viarengo et al. 1985, Viarengo \& Nott 1993). This would explain the relatively high content of ${ }^{109} \mathrm{Cd}$ in the cytosol of the $\mathrm{BB}$ oysters after experimental contamination. In the lysosomes of the BB oysters, the higher percentage of $\mathrm{Cd}$ could result from a more efficient lysosomal system compared to the GE oysters. The presence of the contaminating metal in the environment may have modified the latter's lysosomal physiology, since heavy metals are known to destabilize the lysosomal membranes and disrupt the hydrolytic activity of lysosomal enzymes (Regoli 1992, Viarengo \& Nott 1993).
When contaminated individuals were transferred to clean seawater, the 2 groups of oysters displayed 2-compartment, exponential depuration kinetics. In the short-lived compartment, which contained only 13 to $20 \%$ accumulated $\mathrm{Cd}$, the $\mathrm{Cd}$ was rapidly eliminated in a few days and corresponded to the fraction adsorbed to shell, gills or digestive epithelium after exposure to contaminated water. The significantly higher depuration rate in the short-lived loss component, observed for previously contaminated oysters, could be due to $\mathrm{Cd}$ desorption from the rugose shell, which represented a significantly higher percentage of the $\mathrm{Cd}$ body burden than in oysters from the uncontaminated area.

Based on the results of the subcellular fractionation, the component representing the major portion of accumulated Cd (78 and $86 \%$ with a biological half-life of 6 mo and $1.5 \mathrm{wk}$ for oysters originating from the contaminated and clean areas, respectively) corresponded to the $\mathrm{Cd}$ bound to induced ligands (e.g. metallothioneins) or to lysosomes. Since $\mathrm{Cd}$ in the soluble fraction of oysters is more easily eliminated than the insoluble form (Roesijadi \& Klerk 1989, Geffard et al. 2002), the higher Cd turnover observed for the GE oysters is probably a consequence of the higher percentage of cytosolic $\mathrm{Cd}$, a finding which indicates the presence of an adaptive response in oysters to chronic Cd contamination of marine waters.

The distribution of $\mathrm{Cd}$ between the lysosomes and the cytosolic metallothioneins could also affect the $\mathrm{Cd}$ elimination rates observed for the long-term compartment of loss. Such a mechanism has been hypothesized by Engel (1999), but the elimination process differs according to the metal concerned. During copper contamination, some experiments have shown a transfer of copper from metallothioneins to lysosomes whereby the metal was trapped by the lipofuschins and subjected to exocytosis (George 1990). On the other hand, the transfer of $\mathrm{Cd}$ from metallothioneins to lysosomes does not induce an exocytosis mechanism. The $\mathrm{Cd}$ metallothioneins (which are unstable in the acidic intralysosomal environment) are destroyed, and the metal returns to the cytosol, where it is again trapped by the newly synthesized metallothioneins. In this manner, the toxicity of $\mathrm{Cd}$ is neutralized although the metal remains inside the cell (Viarengo \& Nott 1993).

The presence of rapid and slow Cd elimination processes is comparable to the results obtained by Geffard et al. (2002), who studied Cd elimination in the same species of oysters translocated from the metalenriched GE to a clean site in the BB. The authors, who examined depuration from soft parts of oysters, observed only a single long-term compartment of $\mathrm{Cd}$ elimination with an estimated half-life of $137 \mathrm{~d}$, a value similar to $198 \mathrm{~d}$ recorded in our study. Never- 
theless, in our study the use of a radiotracer demonstrated the presence of a short term compartment of Cd elimination corresponding to the fraction adsorbed to oyster shell. In another depuration study carried out in the field, Van Dolah et al. (1987) recorded a biological half-life of $150 \mathrm{~d}$ for $\mathrm{Cd}$ in the soft tissues of Crassostrea virginica, a value which is also in agreement with our data.

Exposure to chronic $\mathrm{Cd}$ contamination in the marine environment appears to induce a degree of resistance to $\mathrm{Cd}$ in the oyster Crassostrea gigas. From the results obtained at the organism and tissue level, the potential resistance mechanism involved cannot be attributable to a reduction in $\mathrm{Cd}$ permeability but rather to a higher $\mathrm{Cd}$ turnover. Furthermore, the results obtained at the subcellular level revealed a significant amount of $\mathrm{Cd}$ in the cytosolic fraction, in particular associated with metallothioneins, indicating that $\mathrm{Cd}$ is complexed. However, a significant amount of $\mathrm{Cd}$ was also found in the insoluble fraction (termed herein the 'heavy fraction'), mainly associated with the lysosomes. Therefore, through chelation, lysosomes, in parallel with metallothioneins, may be responsible for the reduction in bioavailability and toxicity of $\mathrm{Cd}$ in oysters. Among the differences observed between the 2 populations of oysters is a more rapid response to $\mathrm{Cd}$ contamination in oysters previously exposed to chronic contamination in the marine environment; this is due to the presence of preexisting metallothioneins induced by the elevated $\mathrm{Cd}$ in the contaminated estuarine environment, whereby no essential modification of the metabolic Cd pathway occurs. In addition, the fact that 30 to $40 \%$ of the soluble $\mathrm{Cd}$ (which represents 40 to $60 \%$ of the total $\mathrm{Cd}$ ) was detoxified by the Gironde oysters through chelation to metallothioneins or to lysosomes. This would result in approximately 12 to $24 \%$ of the total $\mathrm{Cd}$ accumulated being potentially bioavailable to humans consuming oysters. However, through depuration processes, $\mathrm{Cd}$ is also more efficiently eliminated from the soft parts (edible parts) of oysters previously exposed to $\mathrm{Cd}$ than from control oysters. Therefore, the manner in which regulatory thresholds of $\mathrm{Cd}$ in oysters are presently calculated should be reconsidered, by taking into account the amount of $\mathrm{Cd}$ already detoxified by the oysters through complexation process.

Acknowledgements. The authors thank Olivier Cotret for his technical assistance with the oyster dissections, and M. D. Saubesty and M. M. Nourry for providing the oysters. This work was partially supported by the French Ministry of Agriculture (Programme AQS). The Marine Environment Laboratory operates under an agreement between the International Atomic Energy Agency and the Government of the Principality of Monaco.

\section{LITERATURE CITED}

Amiard JC (2002) Influence de la speciation et de la biodisponibilité des métaux accumulés par les huîtres sur leur transfer trophique à l'homme et sur leur pouvoir toxique. Rapport final. Contrat AQS du Ministère de l'Agriculture $\mathrm{N}^{\circ} \mathrm{R} 98 / 17$, Université de Nantes/CNRS, Nantes

Amiard-Triquet C (1987a) A study of the quality of the marine environment in the Bay de Bourgneuf through biological indicators of metal pollution. In: Chaussade J (ed) Proceedings of coastal spaces and littoral companies congress, Nantes, 28-30 November 1986, p 133-134

Amiard-Triquet C (1987b) Qualité du milieu marin étudiée en Baie de Bourgneuf à l'aide d'indicateurs biologiques de pollutions métalliques. Norois 34:23-26

Binz PA, Kägi JHR (1999) Metallothionein: molecular evolution and classification. In: Klaassen J (ed) Metallothionein. IV. Birkhäuser Verlag, Basel, p 7-13

Boisset M (1996a) Effets toxiques majeurs du cadmium chez l'animal et l'homme. In: Conseil supérieur d'hygiène publique de France (ed) Plomb, cadmium et mercure dans l'alimentation: évaluation et gestion du risque. Lavoisier Tec \& Doc, Paris, p 119-130

Boisset M (1996b) propositions de valeurs limites pour le cadmium dans les aliments et les boissons. In: Conseil supérieur d'hygiène publique de France (ed) Plomb, cadmium et mercure dans l'alimentation: évaluation et gestion du risque. Lavoisier Tec \& Doc, Paris, p 165

Butler RA, Roesijadi G (2001) Disruption of metallothionein expression with antisense oligonucleotides abolishes protection against cadmium cytotoxicity in molluscan hemocytes. Toxicol Sci 59:101-107

Communautés Européennes (2001) Règlement (CE) N 466/ 2001 de la Commision du 8 mars 2001. JO L $77 \mathrm{du}$ 16.3.2001, L77/1-L77/13. J Officiel, Bruxelles

Coombs TL (1974) The nature of zinc and copper complexes in the oyster Ostrea edulis. Mar Biol 28:1-10

Engel DW (1999) Accumulation and cytosolic partitioning of metals in the American oyster Crassostrea virginica. Mar Environ Res 47:89-102

Fayi L, George SG (1985) Purification of very low molecular weight $\mathrm{Cu}$-complexes from the european oyster. In: Vernberg FJ, Thurnberg FP (ed) Marine pollution physiology: recent advances in marine science, Vol 13. University of South Carolina Press, Columbia, p 145-155

Fisher NS, Stupakoff I, Sanudo-Wilhelmy S, Wang WX, Teyssie JL, Fowler SW, Crucius J (2000) Trace metals in marine copepods: a field test of a bioaccumulation model coupled to laboratory uptake biokinetics data. Mar Ecol Prog Ser 194:211-218

Frazier JM, Georges SG (1983) Cadmium kinetics in oysters - a comparative study of Crassostrea gigas and Ostrea edulis. Mar Biol 76:55-61

Galey J, Goudard F, Pieri J, Germain P, George SG (1986) ${ }^{241} \mathrm{Am}$ binding-components in the digestive gland cells of the marine prosobranch Littorina littorea. Comp Biochem Physiol A 85:333-340

Geffard A, Amiard-Triquet C, Amiard JC, Mouneyrac C (2001) Temporal variations of metallothionein and metal concentrations in the digestive gland of oysters (Crassostrea gigas) from a clean and a metal-rich site. Biomarkers 6:91-107

Geffard A, Amiard JC, Amiard-Triquet C (2002) Kinetics of metal elimination in feral oysters from a contaminated estuary; implications in food hygiene. Comp Biochem Physiol C 131:281-293

George SG (1982) Subcellular accumulation and detoxication 
of metals in aquatic animals. In: Vernberg WB, Calabrese A, Thurberg FP, Vernberg FJ (eds) Physiological mechanisms of marine pollutant toxicity. Academic Press, New York, p 3-52

George SG (1990) Biochemical and cytological assessments of metal toxicity in marine animals. In: Furness RW, Rainbow PS (eds) Heavy metals in the marine environment. CRC Press, Boca Raton, FL, p 123-142

Geret F, Cosson RP (2000) Utilisation des métallothionéines comme biomarqueurs de la contamination métallique: variabilité entre sites et organes chez l'huître Crassostrea gigas. Oceanol Acta 23:261-271

Isani G, Andreani G, Kindt M, Carpene E (2000) Metallothioneins (MTs) in marine molluscs. Cell Mol Biol (Oxford) 46:311-330

Kägi JHR, Vallee BL (1960) Metallothionein: a cadmium- and zinc-containing protein from equine renal cortex. J Biol Chem 235:3460-3465

Langston WJ, Spence SK (1995) Biological factors involved in metal concentrations observed in aquatic organisms. In: Tessier A, Turner DR (eds) Metal speciation in aquatic systems. John Wiley, Chichester, p 407-478

Latouche C (1988) Cadmium pollution in the Gironde estuary. Bull Inst Geol Bass Aquitaine 44:15-21

Latouche C (1992) Cadmium pollution of wild oysters in the Gironde estuary: origin and mechanisms of $\mathrm{Cd}$ fixation. Ichtyophisiol Acta 15:139-152

Lu C, Xie W, Zhou G (1998) Studies on Crassostrea rivularis as a biological indicator of cadmium pollution. J Fish Sci China 5(2):79-83

Luoma SN, Johns C, Fisher NS, Steinberg NA, Oremland RS, Reinfelder JR (1992) Determination of selenium bioavailability to a benthic bivalve from particulate and solute pathways. Environ Sci Technol 26:485-491

Mason AZ, Jenkins KD (1995) Metal detoxification in aquatic organisms. In: Tessier A, Turner DR (eds) Metal speciation and bioavailability in aquatic systems, Vol 3. John Wiley \& Sons, Chichester, p 479-608

Editorial responsibility: Otto Kinne (Editor), Oldendorf/Luhe, Germany
Mouneyrac C, Amiard JC, Amiard-Triquet C (1998) Effects of natural factors (salinity and body weight) on cadmium, copper, zinc and metallothionein-like protein levels in resident populations of oysters Crassostrea gigas from a polluted estuary. Mar Ecol Prog Ser 162:125-135

Regoli F (1992) Lysosomal responses as a sensitive stress index in biomonitoring heavy metal pollution. Mar Ecol Prog Ser 84:63-69

RNO (Réseau National d'Observation) (1995) Surveillance du milieu marin. Trav RNO (Inst Fr Rech Exploit Mer), Paris

Roesijadi G (1996) Environmental factors: response to metals. In: Kennedy VS, Newell RIE, Eble AF (eds) The eastern oysters Crassostrea virginica. Maryland Sea Grant College, University of Maryland, Baltimore, p 515-537

Roesijadi G, Klerk PL (1989) Kinetic analysis of cadmium binding to metallothionein and other intracellular ligands in oyster gills. J Exp Zool 251:1-12

Tanguy A, Mura C, Moraga D (2001) Cloning of a metallothionein gene and characterization of two other cDNA sequences in the Pacific oyster Crassostrea gigas (CgMT1). Aquat Toxicol (New York) 55:35-47

Van Dolah FM, Siewicki TC, Collins GW, Logan JS (1987) Effects of environmental parameters on the elimination of cadmium by eastern oysters, Crassostrea virginica. Arch Environ Contam Toxicol 8:85-95

Viarengo A, Nott JA (1993) Mechanisms of heavy metal cation homeostasis in marine invertebrates. Comp Biochem Physiol C 104:355-372

Viarengo A, Palmero S, Zanicchi G, Capelli R, Vaissiere R, Orunesu M (1985) Role of metallothioneins in $\mathrm{Cu}$ and $\mathrm{Cd}$ accumulation and elimination in the gill and digestive gland cells of Mytilus galloprovincialis Lam. Mar Environ Res 16:23-36

Wang WX, Fisher NS, Luoma SN (1996) Kinetic determination of trace element bioaccumulation in the mussel Mytilus edulis. Mar Ecol Prog Ser 140:91-113

Whicker FW, Schultz V (1982) Radioecology: nuclear energy and the environment, Vol 2. CRC Press, Boca Raton, FL

Submitted: July 23, 2002; Accepted: January 7, 2003

Proofs received from author(s): May 19, 2003 